\title{
KRITIČKI PRIKAZ MONOGRAFIJE DIDAKTIKA NEMAČKE KNJIŽEVNOSTI KAO STRANE, NIKOLINA ZOBENICA, 2018, 246 STR.
}

Mesto i uloga književnosti u nastavi stranog jezika su se tokom godina menjali. Dok je u okviru prvih metoda nastave stranog jezika književnost bila sastavni deo nastavnog procesa, od pedesetih godina prošlog veka se u potpunosti izbacuje iz školske nastave, dok se tokom 1980-ih i 1990-ih godina ponovo pledira za njenu implementaciju zbog značajnih pedagoških ciljeva koji se njome ostvaruju. Tokom 1980-ih godina nastaju i prve didaktike književnosti u Nemačkoj i to u kontekstu nastave maternjeg jezika, dok su didaktike nemačke književnost kao strane izuzetno malobrojne i to ne samo u zemljama nemačkog govornog područja već i na evropskom tlu. Začetnik didaktike književnosti kao strane na ovim prostorima upravo je autorka monografije prof. dr Nikolina Zobenica. Objavljivala je najpre prve radove na ovu temu, a kasnije uvela predmete Književnost u nastavi nemačkog jezika i Žanrovi nemačke dečje književnosti na studijskom programu Nemački jezik i književnost, na Filozofskom fakultetu Univerziteta u Novom Sadu, koji imaju za cilj da studente germanistike upoznaju sa sadržajima i tekstovima koji su bliski interesovanjima dece i omladine, kao i sa inovativnim pristupima i metodama u nastavi književnosti kao strane kako bi se kod učenika razvijale analitičke sposobnosti, ali i kreativnost, mašta, radost i ljubav prema književnosti i nemačkom jeziku. Radi se dakle o jednom dugogodišnjem, istrajnom i posvećenom radu autorke u oblasti didaktike nemačke književnosti kao strane čiji vrhunac upravo predstavlja ovo delo.

Monografija Didaktika nemačke književnosti kao strane ima 245 strana, strukturisana je u 14 poglavlja, na početku monografije nalazi se predgovor autorke, a na kraju završna razmatranja i spisak literature. U uvodnom delu, prof. dr Nikolina Zobenica skicira predmet i ciljeve proučavanja didaktike književnosti na stranom jeziku, navodi metodološki pristup koji je korišćen prilikom sakupljanja građe i njene obrade, i ukazuje na tri osnovne tematske celine koje postoje u radu prva koja ukazuje na ciljeve nastave književnosti, druga na sadržaje, a treća na metode rada.

U okviru prve tematske celine, koja obuhvata drugo i treće poglavlje, definiše se predmet proučavanja metodike i didaktike nemačkog kao stranog jezika 
pri čemu autorka uspešno obrazlaže pojam „metodika”, a u drugim poglavljima i pojam „metoda”, koji predstavlja jedan od najproblematičnijih kategorija u okviru didaktike, a posebno se usložnjava u kontekstu didaktike stranog jezika. Nakon toga autorka uvodi i definiše pojam „didaktika književnosti” i ukazuje na mesto i značaj književnosti u nastavi stranog jezika, pozivajući se na čuvenog didaktičara književnosti, Jirgena Kopenštajnera, koji ističe da je nastava jezika podnošljiva samo zbog književnosti. Da bi se utvrdili razlozi za marginalizovano mesto nemačke književnosti u našoj zemlji, autorka analizira programe u gimnazijama za prvi i drugi strani jezik i zaključuje da spiskovi za čitanje knjiga na nemačkom jeziku ne spadaju u književnost za mlade, već u opštu književnost i deo su kanona, te je neophodna njihova revizija $u$ cilju približavanja književnosti interesovanjima mladih ljudi i njihovim jezičkim kompetencijama.

Druga celina monografije, koja se bavi sadržajima u nastavi književnosti, obuhvata poglavlja od 4. do 7. U četvrtom poglavlju N. Zobenica iznosi kriterijume za izbor tekstova u nastavi i tematizuje problem primene kanonskih dela u nastavi književnosti kao strane. Osim toga, ukazuje na značaj primene savremene i dečje književnosti, kao i mogućnost primene didaktizovanih književnih tekstova. U narednom poglavlju, prof. dr Nikolina Zobenica produbljuje datu temu baveći se žanrovima pri čemu navodi potencijale svakog žanra za nastavu književnosti kao strane. Od epskih vrsta autorka posebno ističe efikasnost kraćih formi kao što su bajka i kratka priča, dok je lirika posebno pogodna za kreativne i produktivne zadatke, a drama za scensko izvođenje. Osim ove standardne podele književnih žanrova, autorka ističe značaj filma kao četvrtog književnog roda za nastavu strane književnosti i predočava pristupe koji se mogu koristiti za njegovu adekvatnu obradu i implementaciju u nastavu. Šesto poglavlje posvećeno je medijima kao sastavnim delovima nastave književnosti, u kojem autorka, pored tradicionalnih, ističe i značaj primene modernih i digitalnih medija u cilju osavremenjavanje nastave i približavanja književnosti deci i omladini. Posebno je značajno što autorka skreće pažnju na primenu platformi za učenje, definiše pojmove elektronsko učenje (E-learning) i kombinovano učenje (blended learning) i ukazuje na mogućnost primene pametnih telefona u nastavi književnosti. Primenom pomenutih medija nastava književnosti dobija novu dimenziju, povezuje se sa svakodnevnim životom mladih, aktivira različite tipove i stilove učenja, omogućava diferencijaciju u nastavi, kao i različite pristupe u radu sa književnim tekstom. U sedmom poglavlju tematizuje se povezivanje književnosti i drugih predmeta i umetnosti u cilju prevazilaženja granica među predmetima i stvaranje funkcionalnih znanja neophodnih u globalizovanom društvu. U ovom kontekstu Zobenica definiše pojam ,integrativne nastave” i zaključuje da su otvorena i 
projektna nastava kao nastavni koncepti posebno pogodni za integrativnu nastavu pre svega zato što u prvi plan stavljaju učenike i njihova interesovanja. Ovim autorka pokazuje da i te kako dobro poznaje savremene tendencije u didaktici jezika i književnosti, i veoma uspešno povezuje i prenosi saznanja iz oblasti didaktike maternjeg jezika i književnosti na didaktiku stranog jezika i književnosti.

Treća celina monografije obuhvata poglavlja od 8. do 11. u kojima se obrađuju sledeće teme: metode $\mathrm{u}$ nastavi književnosti, vežbe i zadaci, faze u nastavi, priprema časa nemačke književnosti i vrednovanje postignuća. Ovaj deo monografije je izuzetno značajan jer daje nastavnicima praktična uputstva za primenu odgovarajućih nastavnih metoda i zadataka u određenim fazama nastavnog časa, za organizaciju i artikulaciju časa književnosti i vrednovanje postignuća učenika. Ovde se, dakle, radi o čitavom kontekstu koji nastavnik mora poznavati da bi uspešno primenio književnost u praksi.

Veoma je važan odeljak u kojem N. Zobenica nudi uputstva i strategije u radu sa književnim tekstovima. Pogrešan rad sa tekstom dovodi do pogrešne recepcije književnosti i njenog nerazumevanja. Autorka je prepoznala glavne probleme sa kojima se nastavnici susreću u praksi i u ovom odeljku nudi konkretne korake za njihovo prevazilaženje. Pored vežbi za razvoj jezičkih kompetencija, prof. dr Nikolina Zobenica navodi vežbe i zadatke za interkulturalna poređenja u cilju razvoja interkulturalne kompetencije koja je od ključnog značaja u globalizovanom društvu. U desetom poglavlju predočeno je nekoliko modela za pripremu časa strane književnosti, a odabir treba da sledi postavljene ciljeve, kompetencije, sposobnosti i interesovanja učenika. Modeli doprinose postojanju jasne strukture u radu sa književnim tekstom i od velike su pomoći nastavnicima u strukturisanju nastavnog časa. U poslednjem poglavlju autorka se bavi problematikom ocenjivanja u nastavi književnosti. Književni tekstovi su do sada predstavljali sredstvo za vrednovanje veštine čitanja, dok su ostali aspekti rada sa književnim tekstom, poput razvoja analitičkih veština, formiranja stavova, sticanje književnog znanja i kreativno-produktivni rad, bili zapostavljeni. Autorka predlaže da se ove veštine proveravaju preko eseja, domaćih radova i portfolija, što je izuzetno značajno, jer time nastavnik ima mogućnost da proverava različite aspekte rada na književnom tekstu. Ukazuje se i na mogućnost primene tehnike samoocenjivanja i neformalnih izveštaja, kako bi kriterijumi u vrednovanju postignuća bili jasniji i transparentniji.

U Literaturi je navedeno 196 bibliografskih jedinica na srpskom, engleskom i nemačkom jeziku što svedoči o izuzetno temeljnom radu i istraživanju. Osim toga, radi se o pionirskom radu iz ove oblasti u Srbiji i regionu što je čini izuzetno vrednom kako za naučnu tako i stručnu javnost. Sva poglavlja u 
knjizi napisana su vrlo kompetentno, jasno i razumljivo i predstavljaju osnov za proveravanja teorijskih znanja i postavki u praksi i sprovođenje daljih istraživanja u cilju unapređenja nastavne prakse, kao i utemeljenje didaktike nemačke književnosti kao strane u našoj zemlji.

Zbog svoje praktične primene, monografija je namenjena profesorima stranog i maternjeg jezika, kao i univerzitetskim profesorima koji predaju književnost strane i domaće filologije, budući da autorka u monografiji uvek polazi od opšteg (didaktike književnosti maternjeg jezika) ka posebnom (didaktike strane/nemačke književnosti). Dobro osmišljena nastava književnosti od ključnog je značaja za razvijanje motivacije za čitanje, pismenosti, kritičkog mišljenja, kreativnosti, mašte, tolerancije $i$ širine, te je potreba za ovakvom monografijom i više nego velika, a njena korist neprocenjiva.

\author{
Ana I. Stipančević \\ Univerzitet u Novom Sadu \\ Filozofski fakultet, Odsek za germanistiku \\ ana.stipancevic@ff.uns.ac.rs
}

Primljeno: 15. 5. 2019.

Prihvaćeno: 30. 5. 2019. 